Jusmal lemiah
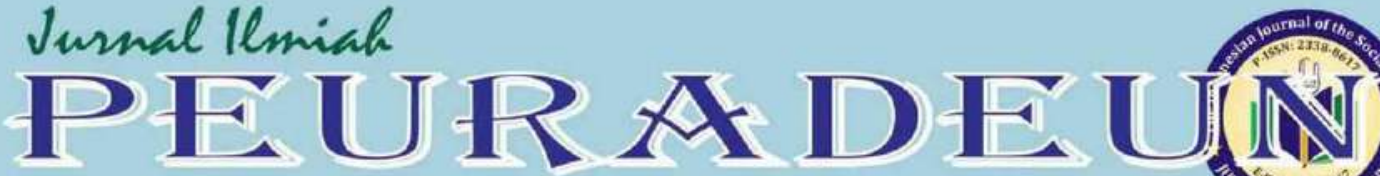

Vol. 6, No. 1, January 2018

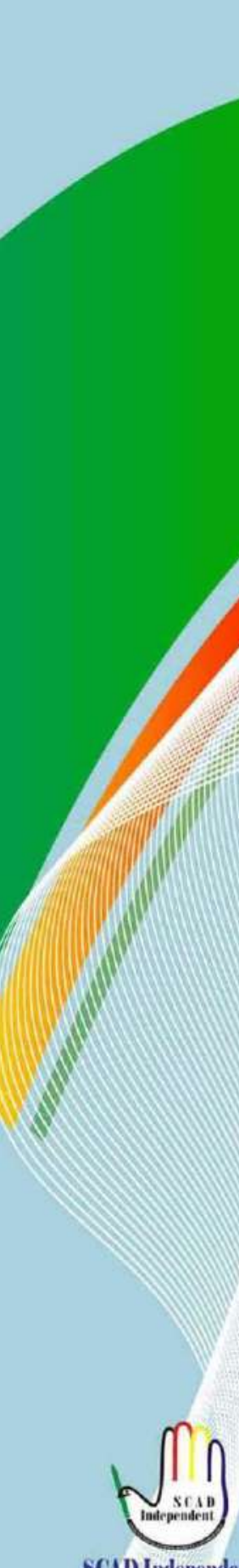

SCAI) Independent Accreditatioa by HO since 2014 $\bigodot$ Copernicus Publications

\section{III}

The Indonesian Journal of the Social Sciences www.journal.scadindependent.org Dot Prefix Number: 10.26811

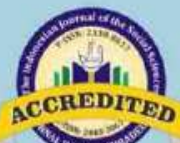

ACCREDITED - B" by the Ministry of Risteklikti from Oetaber 30, 2017 until Oetober 30, 2022

\section{Clarivate Analytics}

Emerging Sources Citation Index Web of Science ${ }^{\mathrm{TM}}$

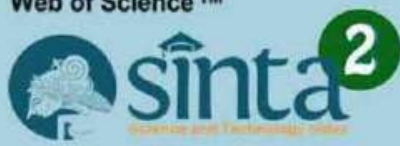
INDEX $\circledast$ COPERNICUS 


\title{
LITERATURE STUDY: ROLE OF SELF-EFFICACY TOWARD STUDENTS' ACHIEVEMENT IN MATHEMATICAL MULTIPLE REPRESENTATION ABILITY (MMRA)
}

\author{
Mutia Fonna ${ }^{1} \&$ Mursalin $^{2}$ \\ 1,2Universitas Malikussaleh, Aceh Utara, Indonesia \\ ${ }^{1}$ Contibutor Email: mutia.fonna@unimal.ac.id
}

\begin{abstract}
Various studies showed that there are some points which affect students' achievement; one of them is mathematics self-efficacy. Self-efficacy is feeling, trust, and confidence of affective behavior of students toward their ability. In learning process, the students find obstacles in solving their problem such as relating one representation to another representation. Previous studies indicated that students' achievement of mathematical representation ability have obstacles because the students did not understand relationship between concepts, ideas, and materials to be represented. The other studies claimed that the higher students' self-efficacy, the higher mathematical multiple representation ability (MMRA). It means that self-efficacy has positive correlation with mathematic ability. This article will discuss about role of mathematics self-efficacy toward ability achievement of mathematical multiple representation ability (MMRA) in solving mathematics problem in order to increase students' achievement.
\end{abstract}

Keywords: Self-efficacy, Mathematical Multiple Representation Ability (MMRA) 


\section{A. Introduction}

The development of science and technology led to dynamic changes of life globally. One of the most influential areas and underlying the development of modern technology is mathematics. To master the technology and to create in the future required the existence of a mastery of math at early stages. The humans exist potential in mathematics further developed by studying the different fields of mathematics.

Various mathematical skills are expected to be achieved in learning mathematics from elementary school up to high school. National Council of Teachers of Mathematics (NCTM) in 2000 in a book entitled ' Principles and Standards for School Mathematics' stated that five mathematical skilss that should be mastered by students namely:(1) mathematical communication; (2) mathematical reasoning; (3) mathematical problem solving; (4) mathematical connection; (5) mathematical representation.

Mathematical skills that should be mastered by students at the level of primary and secondary education should also have to be mastered by math teachers' candidate. At the level of higher education, learning and thinking mathematics in College has been a concern of Committee on the Undergraduate Program in Mathematics or the CUPM (2004), which proposed some basic recommendations to departments, programs, and courses in mathematics. One of the recommendations explains that each course activities in mathematics should assist students in the development of analytical, critical reasoning, problem solving, and communication skills. The CUPM recommendations above explains, the responsibility of the educational institution is to educate teachers' candidate who will teach math in the future, which is preparing them to have the communication skills and critical thinking mathematically. In terms of communication, the candidates of teachers are able to present the key ideas and concepts from a variety of perspectives such as wide range of examples and applications to motivate and to illustrate the material.

The achievement of ability in learning math such as thinking, communication, connection, problem solving and so on require a means of communication in oral or written. The means of communication may take the 
form of single or multiple representation, who can communicate mathematical ideas in a certain way. Hiebert (Dewanto, 2007) stated that each time communicates the idea of math, these ideas need to be presented in a certain way. Various forms of mathematical language to communicate one's ideas to others or himself in solving problems, it can be in the form of graphs, tables, images, and so on. Wahyuni (2012:4) suggested that a complex problem would be much simpler if you use a representation that corresponds to a given problem, otherwise erroneous representations of the construction makes the problem difficult to be solved.

In fact the implementation is not an easy thing, even though representation is a standard to be achieved in learning mathematics. Yerushalmy (Dewanto: 2008) argues for the implementation of the learning of mathematics in College, there are many obstacles faced by students including students' difficulty in bridging a representation with other representations or move from one representation to other representations. Other things also pointed out that in the achievement of the capability of representation of students experiencing constraints, whereas he did not understand the basic concepts, ideas or material to be represented. The statement indicated that the ability of understanding the concepts and relation between mathematical concepts is necessary to achieve the capabilities of multiple mathematical representations (MMRA).

Phenomenon the important of mathematical ability particularly multiple representation to enhance learning achievements are inseparable from the attitudes and beliefs that exist on someone in solving the problem. In the last few years the afective domain attracted the attention of many mathematical researcher community (Philippou \& christou, 2002). It is also expressed by Dewanto (2008) which posited that in learning process student also require high affective behavior in order to resolve the various problems encountered in mathematical tasks. The beliefs that exist in a person encourage understanding deeply why a person is experiencing failure or success. Stuart (2000) stated that the students' low-confidence causes the rise of mathematical anxiety. It resulted in a low level of mathematical ability of students. One of the afective domain components is self-efficacy beliefs (Goldin, 2002). 
Self-efficacy has an impact on motivation, so it deals with student success in learning. A student who has high self-efficacy will try hard to achieve their successful in learning. Otherwise, if the student that has low self-efficacy, they tend to avoid the assignment or unmotivated in doing it so that they will give up quickly if they face the obstacle (Schunk, 1985).

Therefore self-efficacy is strongly needed in students to be succeed in learning mathematics. Gagatsis \& Sophocleous (2009) found that highability students had stronger and more accurate efficacy beliefs towards the volume measurement tasks in comparison to low-ability students.

Based on its urgency, self-efficacy should be developed in order to improve students' achievement. In this article, the role of mathematical selfefficacy will be examined towards students' achievement of the multiple mathematical representations ability (MMRA) with the hope that students can solve math problems, and increase on student learning achievement.

\section{B. Discussion}

\section{Self-Efficacy}

Self-Efficacy is the person's ability to affect the expected results. Based on some experts, Self-Efficacy on its implementation would be the same with "Confidence" or "Self Confidence". Confidence is a positive attitude of an individual who makes him able to develop positive assessment both against yourself or against the environment/situation that was faced. To foster a sense of confidence that is proportional individuals should start it within yourself. This is important for students who have low confident to overcome their self confidence.

Self-Efficacy is based on social cognitive theory Bandura. Bandura (1997) in his book entitled ' Self-Efficacy: The Exercise of Control describes that Self-Efficacy will affect the action, effort, persistence, flexibility in the difference, and the realization of the individual objectives, so that Self-Efficacy related to a person's ability often determines the outcomes before the action occurs.

According to Bandura (Soemakim, 2010-12:51), Self-Efficacy is central in the construction of social cognitive theory owned by someone: (1) Affect 
on decision making, and influence on the action going to do by someone; (2) Help how much effort he acted in an activity, how long he survived when got in trouble, and how flexible in a situation less favorable for him. The greater Self-Efficacy of a person, the greater the effort, persistence, and flexibility; (3) affects on the mindset and emotional reactions.

Further Bandura (1997:80-115) suggests that there are four major sources affecting self-efficacy (1) authentic Experience (authentic mastery experiences); (2) the experience of others (various experience); (3) social or verbal Approach; (4) psychological Index, where physical and emotional status will affect a person's ability.

\section{Multiple Mathematical Representation Ability (MMRA)}

To communicate mathematical ideas, someone needs to represent those ideas in a certain way. According to Dewanto (2007:8) representation appeared as part of mathematical communication. Representation is essentially a part of mathematical communication which can be shaped as a regular language (ordinary language), mathematical verbal language, symbols language, visual representation, and quasi-mathematical language. The above representation serves to communicate mathematical ideas.

Representation is one of the skills that should be mastered by the student. Jones and Knuth (1991) suggest that there are some reasons for the important of representation ability, namely: the basic ability to build concepts and mathematical thinking, and to have a good understanding of capabilities in order to be used in problem solving. In problem solving, initiated by the presence of a representation against the definition of the problem presented. The understanding of the definition issue will encourage the creation of a representation that leads to the problem-solving process.

Cai, Lane and Jacabcsin (1996:243) stated that the multiple representation that frequently used in communicating mathematics include: tables, images, graphs, mathematical statements, written text, or a combination of all. In its process, Dewanto (2008) suggests that the ability of multiple mathematical representations (MMRA) does not occur in an isolated space, but formed in a structured system. 
In terms the appearance of the representation, there are three types of representation, they are: internal, external, and internal-external or shared representation (shared representation). Goldin (2002:210) suggests that the internal Representation is a process of thinking about mathematical ideas that allow one to work on the basis of those ideas, the process of internal representation cannot be observed with the naked eye and cannot be assessed directly because it is a person's mental activity in his mind (minds on). External representation is the result of an embodiment to describe anything that's been done internally may be released either orally (talk) or written (write) in the form of words (words), symbols, expressions, or mathematical notations (mathematical expressions or equations), images (pictures), graphs (graphs), diagrams (diagrams), tables (tables) or through physical objects as media (hands on).

\section{Relationship between self-efficacy and Mathematical Multiple Representation Ability (MMRA)}

There are some factors that affect the students' achievement in learning, one of them is the belief in themselves. The belief or confidence called self-efficacy has a role in the learning achievements particularly the mathematical multiple representation ability (MMRA). The student who has a strong belief, if faced with tasks related to the ability of mathematical representation will be able to accurately resolve the issue. Instead of someone with low confidence will feel difficult in resolving the issue. It is in accordance with the results of the author's observations toward the student as well as previous studies, the students who have confidence in themselves do not feel hesitant or confused in the representation either internally or externally, rather those who had doubts in themselves would feel anxious and difficult in representing mathematical tasks.

\section{Relevant Studies}

Various studies show that there are some things that affect student learning achievement such as self-efficacy mathematically. Nurfauziah (2012) suggests that there is a relationship between the mathematical 
connection capability and self-efficacy of students. Sri (1999) States that there is a relationship between the mathematical communication skills and self-efficacy. In line with Handayani (2011) who suggests that there is a significant relationship between the mathematical problem solving of students capability and self-efficacy of students with medium qualifications. Based on previous studies above either the middle or elementary school level, mathematical ability of students affected by the afective domain called self-efficacy.

At the level of higher education, many obstacles are faced by the implementation of the mathematics learning including students' difficulty in bridging a representation to other representations or move from one representation to the other representations. Dewanto (2008) shows that the higher self-efficacy of college students, the higher the ability of mathematical multiple representations (MMRA), meaning that self-assurance is correlated positively with their mathematical ability. A high self efficacy gives a great influence towards the ability of mathematical representation which impact on the ability to understand mathematical concepts.

\section{Conclusion}

Based on the results, the researcher hypothesize that theoretically mathematical multiple representations ability (MMRA) of students influenced by the efective domain especially self-efficacy. The higher selfefficacy of the students then the higher the ability for multiple representations of strings (MMRA). Further study is needed related to multiple representations of mathematical ability which is affected by selfefficacy, not only on primary and secondary education but also in higher education, by applying variety learning materials.

\section{Bibliography}

Abtahi, M., \& Battell, C. (2017). Integrate Social Justice Into the Mathematics Curriculum in Learning. Jurnal Ilmiah Peuradeun, 5(1), 101-114. 
Bandura, A. (1997). Self-Efficacy: The Exercise of Control. [Online].Tersedia: http:/www.amazon.com/Self-Efficacy/Exercise.AB/fdf.[11 April 2017].

Cai, J., Lane,S., dan Jacabcsin, S.M. (1996). Assessing Student's Mathematical Communication. Journal School Science and Mathematics. 96 (5), 238-246.

CUPM (2004). Undergraduate Programs and Courses in the Mathematical Science: CUPM Curriculum Guide 2004. USA: The Mathematical Association of America.

Dewanto, S.P. (2007). Upaya Meningkatkan Kemampuan Multipel Representasi Matematik Melalui Pembelajaran Berbasis Masalah. Disertasi. SPs UPI. Bandung: tidak diterbitkan.

Dewanto, S.P. (2008). Peranan Kemampuan Akademik Awal, SelfEfficacy, dan Variabel Nonkognitif Lain Terhadap Pencapaian Kemampuan Representasi Multipel Matematis Mahasiswa Melalui Pembelajaran Berbasis Masalah. Educationist, 2(2), 123-133.

Gagatsis, A., \& Sophocleous, P. (2010). Efficacy Beliefs And Ability To Solve Volume Measurement Tasks In Different Representations. CERME. 6, 74-83.

Goldin, A. (2002). Representation in Mathematical Learning and Problem Solving. Dalam English, L. D (Ed) Handbook of International Research in Mathematics Education (pp: 197-218). Mahwah, New Jersey: Lawrence Erlbaum Associated, Inc.,

Handayani, I. (2011). Penggunaan Model Method Dalam Pembelajaran Pecahan Sebagai Upaya Meningkatkan Kemampuan Pemecahan Masalah Matematik dan Self-Efficacy Siswa Sekolah Dasar. Tesis SPs UPI: Bandung. tidak diterbitkan.

Jones, B.F. dan Knuth, R.A. (1991). What does Research Say about Mathematics? [Online].Tersedia:http://www.ncrl.org/sdrs/stwesys/2math.html.[11 April 2017]

Kaylene, P., \& Rosone, T. L. (2016). Multicultural Perspective on the Motivation of Students in Teaching Physical Education. Jurnal Ilmiah Peuradeun, 4(1), 115-126.

NCTM (2000). Principles and Standards for School Mathematics. Reston, VA: NCTM 
Nurfauziah, P. (2012). Peningkatan Kemampuan Koneksi Matematis dan SelfEfficacy Siswa SMP Melalui Pembelajaran Matematika Model Core. Tesis SPs UPI. Bandung: tidak diterbitkan.

Pamela, C., Villalobosl, L., \& Peralta, N. (2017). Difference Cultural Structure and Behavior Students In Learning Process. Jurnal Ilmiah Peuradeun, 5(1), 15-24.

Philippou, G. \& Christou, C. (2002). A study of the mathematics teaching efficacy beliefs of primary teachers. In G.C. Leder, E. Pehkonen, \& G. Törner (Eds.), Beliefs: A hidden Variable in Mathematics Education? (pp. 211-231). Netherlands: Kluwer Academic Publishers.

Safrina, S., \& Saminan, S. (2015). The Effect of Model Problem Based Learning (PBL). Jurnal Ilmiah Peuradeun, 3(2), 311-322.

Saifullah. (2015). The Internalization of Democratic Values into Education and Their Relevance to Islamic Education Development (Synthetic, Analytic, and Eclectic Implementation of John Dewey's Thoughts). Advanced Science Letters, 21 (7), 2301- 2304, DOI: $10.1166 /$ asl.2015.6257

Schunk, D. H. \& Hanson, A. R. (1985). Peer Model: Influence on Children's Self Efficacy and Achievement. Journal of Educational Psychology, 77, 313-322.

Somakim (2010). Peningkatan Kemampuan Berpikir Kritis dan Self-Efficacy Matematik Siswa Sekolah Menengah Pertama dengan Penggunaan Pendekatan Matematika Realistik. Disertasi SPs UPI. Bandung: tidak diterbitkan.

Sri, R. O (2016). Penerapan Model Pembelajaran Kooperatif Tipe Course, Review, Horay (CRH) terhadap kemampuan komunikasi matematis dan self-efficacy siswa. Tesis. PPs Universitas Pasundan. Bandung: tidak diterbitkan.

Stuart, V. (2000). Math Curse or Math Anxiety?. Teaching Children Mathematics, 6 (5), 330-335.

Sulaiman, S. (2015). Classroom Management and the Implications to Quality of Learning. Jurnal Ilmiah Peuradeun, 3(3), 431-440.

Suzanne, R., \& Nathalie, L. (2016). Multiculturalism as an Alternative A Cultural Orientation to Education in the Aspect of Culture as the Axiological Focus. Jurnal Ilmiah Peuradeun, 4(3), 383-394. 
Tabrani. ZA \& Masbur, M. (2016). Islamic Perspectives on the Existence of Soul and Its Influence in Human Learning (A Philosophical Analysis of the Classical and Modern Learning Theories). Jurnal Edukasi: Jurnal Bimbingan Konseling, 1(2), 99-112.

Vitoria, L., \& Monawati, M. (2016). Improving Students' Problem Solving Skill in Mathematics Through Writing. Jurnal Ilmiah Peuradeun, 4(2), 231-238.

Wahyuni, S. (2012). Peningkatan Kemampuan Representasi Matematis dan Self Esteem Siswa Sekolah Menengah Pertama dengan Menggunakan Model Pembelajaran ARIAS. Tesis SPs UPI. Bandung: tidak diterbitkan.

Walidin, W., Idris, S \& Tabrani. ZA. (2015). Metodologi Penelitian Kualitatif dan Grounded Theory. Banda Aceh: FTK Ar-Raniry Press. 